\title{
Population Dynamics of Omiodes indicata (Fabricius) (Lepidoptera: Pyralidae) on Soybean in Brazil
}

\author{
Bruna M. Favetti ${ }^{1}$, Bruna Catoia ${ }^{2}$, Thais G. Gericó ${ }^{3} \&$ Regiane C. O. F. Bueno ${ }^{2}$ \\ ${ }^{1}$ Instituto Agronômico do Paraná, Londrina, PR, Brazil \\ ${ }^{2}$ Faculdade de Ciências Agronômicas, Universidade Estadual Paulista Júlio de Mesquita Filho, Botucatu, SP, \\ Brazil \\ ${ }^{3}$ Faculdade de Ciências e Engenharia, Universidade Estadual Paulista Júlio de Mesquita Filho, Tupã, SP, Brazil \\ Correspondence: Bruna M. Favetti, Instituto Agronômico do Paraná, Rodovia Celso Garcia Cid, km 375, \\ Londrina 86047-902, PR, Brazil. E-mail: favettibruna@yahoo.com.br
}

Received: August 20, 2017

Accepted: November 15, 2017

Online Published: December 15, 2017

doi:10.5539/jas.v10n1p245

URL: https://doi.org/10.5539/jas.v10n1p245

\begin{abstract}
An observed increase in the populations of Omiodes indicata (Fabricius) in Brazil's soybean crops is causing population outbreaks. Specimens were collected at Experimental Farm Lageado, in São Paulo State University (UNESP), Faculty of Agronomic Sciences, Botucatu, São Paulo, Brazil. Samples of individuals (larvae and pupae) were collected in the field and kept in the laboratory until emergence of adults to confirm the species. The species $O$. indicata occurred in four soybean areas with no previous record of this pest. The population dynamics showed that this lepidopteran is present throughout crop development, with population peaks occurring during the reproductive period of soybean. These observations are unique to this crop and planting site, showing that the insect has been adapting to the conditions of the region where it was found, demanding attention from soybean producers.
\end{abstract}

Keywords: Glycine max, secondary pest, population fluctuation

\section{Introduction}

The main species of larvae defoliating soybean crops in Brazil are Chrysodeixis includens (Walker) (Lepidoptera: Noctuidae), Anticarsia gemmatalis (Hübner) (Lepidoptera: Erebidae), Spodoptera eridania (Cramer), S. frugiperda (Smith) and S. cosmioides (Walker) (Lepidoptera: Noctuidae) and species of the subfamily Heliothinae (Bortolotto et al., 2015; Wiest \& Barreto, 2012; Czepak et al., 2013). There are sporadic infestations of other Lepidoptera species, such as Omiodes indicata (Fabricius) (Lepidoptera: Pyralidae), Urbanus proteus (Linnaeus) (Lepidoptera: Hesperiidae) and Trichoplusia ni (Hübner) (Lepidoptera: Noctuidae) (Moscardi et al., 2012), especially in the absence of factors that keep them below the control level, leading to population outbreaks and causing damages.

The species $O$. indicata, also known in the scientific literature by the synonym Hedylepta indicata (Fabricius, 1775) (Bortoli et al., 1982), is a secondary pest popularly known as leaf roller. Highlighting the increase in its occurrence rate on soybean in tropical and subtropical regions, the species has been recorded attacking this crop in Asia, the USA, Dominican Republic, Puerto Rico, Cuba, Nicaragua, Suriname, French Guiana and Brazil (Moscardi et al., 2012; Plantwise, 2017).

Intense outbreaks of $O$. indicata were recorded in Brazil during the agricultural years of 2004/2005 and 2009/2010 in the states of Paraná, Mato Grosso do Sul, Mato Grosso, Goiás, Bahia, Maranhão, Piauí, Tocantins and Pará (Meyer, Moscardi, \& Sosa-Gómez, personal communication apud Moscardi et al., 2012).

Larvae of $O$. indicata are easily recognizable due to their habit of rolling and joining soybean leaflets through secretions and silk threads forming a shelter where they spend the entire larval stage (Sosa-Gómez et al., 2010). The larvae have a green and oily appearance. They can measure 12 to $15 \mathrm{~mm}$ by the end of larval development that lasts from 14 to 28 days and consists of five stages (Bortoli et al., 1982; Sosa-Gómez et al., 2010).

Due to the occurrence of populations outbreaks, research on the occurrence and population dynamics throughout the development of soybean is the key to planning control strategies in situations of outbreaks in crop regions. 
Thus, this study aimed to report the occurrence and population dynamics of $O$. indicata in areas with soybean crops in Brazil.

\section{Methods}

\subsection{Experimental Area and Crop Cultivation}

The specimens were collected in four areas $\left(22^{\circ} 48^{\prime} 24.14^{\prime \prime} \mathrm{S}, 48^{\circ} 25^{\prime} 39.30^{\prime \prime} \mathrm{O} ; 22^{\circ} 49^{\prime} 30.40^{\prime \prime} \mathrm{S}, 48^{\circ} 25^{\prime} 34.04^{\prime \prime} \mathrm{O}\right.$; $\left.22^{\circ} 49^{\prime} 12.94^{\prime \prime} \mathrm{S}, 48^{\circ} 25^{\prime} 48.74^{\prime \prime} \mathrm{O} ; 22^{\circ} 48^{\prime} 02.71^{\prime \prime} \mathrm{S}, 48^{\circ} 25^{\prime} 24.48^{\prime \prime} \mathrm{O}\right)$ at the Lageado Experimental Farm belonging to FCA/UNESP, Botucatu (SP), cropped with soybean (cultivar BMX Potência RR) at a spacing of $45 \mathrm{~cm}$ and occupying three hectares in each area, all totalling 12 hectares.

The soybean was planted in December 2015 under a no-tillage system. The seeds were treated with fungicide (60 $\mathrm{g}$ a.i. carboxine $+60 \mathrm{~g}$ a.i. thiram) and insecticide ( $70 \mathrm{~g}$ a.i. thiamethoxam) for $100 \mathrm{~kg}$ of seeds, followed by the inoculation of Bradyrhizobium ( $60 \mathrm{ml} / 50 \mathrm{~kg}$ of seeds).

Application of pesticides followed recommendations by the Agrochemicals Phytosanitary System (AGROFIT) and approved by the Ministério da Agricultura, Pecuária e Abastecimento (MAPA). Asian rust was preventatively controlled using the fungicide azoxystrobin $(60 \mathrm{~g} / \mathrm{ha}$ a.i. $)+$ cyproconazole $(24 \mathrm{~g} / \mathrm{ha}$ a.i. $)$ supplemented with mineral oil adjuvant $(0.5 \%$ of the application volume). The herbicide Glyphosate was applied at a rate of $2 \mathrm{~L} / \mathrm{ha}$.

\subsection{Sampling of Insects}

The sampling was done weekly in the period between December 2015 and April 2016 by monitoring 60 points/area during the vegetative stages (V1-V4) and after the V4 stage of crop development. The beat cloth method developed by Boyer and Dumas (1963) was used. The collected individuals (larvae and pupae) were placed in plastic containers and kept under laboratory conditions $\left(25 \pm 2{ }^{\circ} \mathrm{C}, \mathrm{RH}=70 \pm 10 \%\right.$ and photoperiod $=12$ hours) until adult emergence, after which time the identification of species was confirmed.

\section{Results and Discussion}

Evidence of $O$. indicata feeding on soybean was found in all four experimental areas (Figure 1). Larvae were collected from the V4 to R8 stages of crop development. The larvae fed by scraping the leaf parenchyma and in severe attacks, they reduced leaf area, which reduces the photosynthetic capacity. Due to their habit of 'rolling' and attaching to the leaves, the larvae are protected from contact insecticides, thus making them more difficult to control (Quintela \& Barrigossi, 2005; Moscardi et al., 2012).

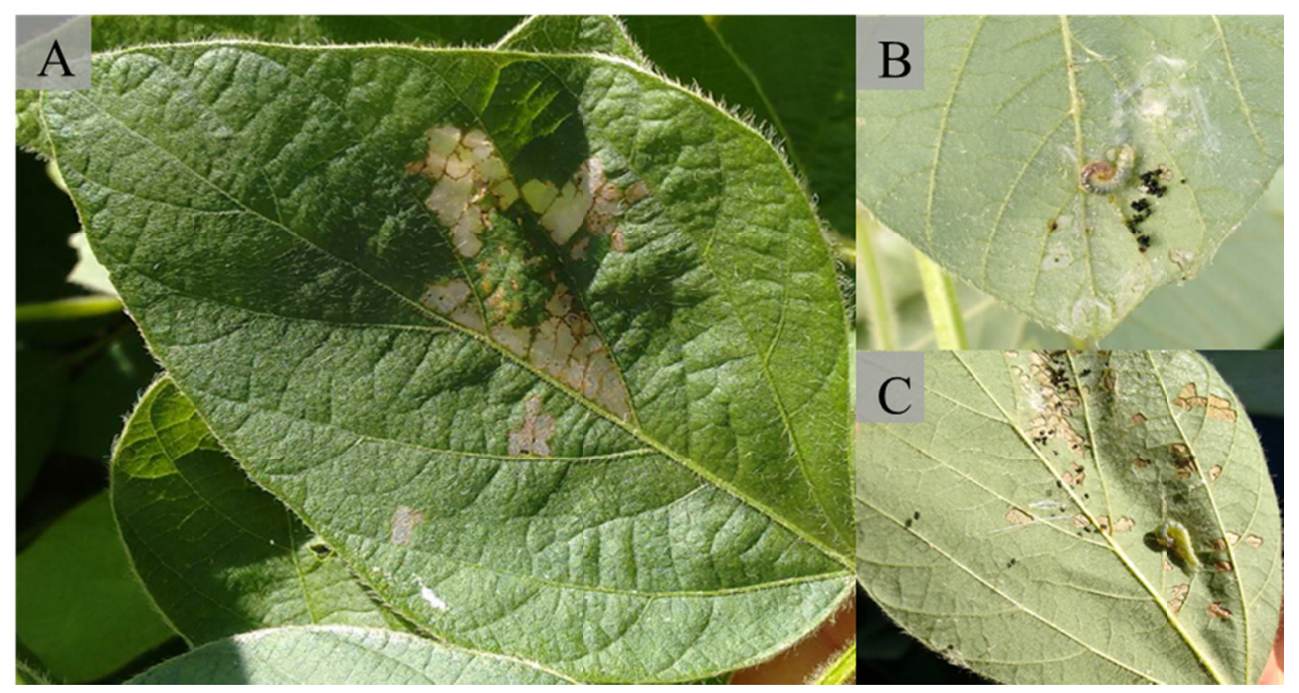

Figure 1. Omiodes indicata causing defoliation in soybean. (A) Consumed area; (B and C) Larvae feeding on soybean leaves

Although the lepidopteran populations colonized the crop from the beginning of development, the increase in the number of individuals occurred early in the reproductive stage of soybean with population peaks during the R5 (pod filling) stage (Figure 2). Limonte et al. (2016) observed a similar scenario in Cuba during his experiments 
with soybean, observing that $O$. indicata was present throughout the crop cycle, causing greater damage in areas practising the no-tillage system and peaking between the 42nd and 58th days, which correspond to the R4 and R5 stages.

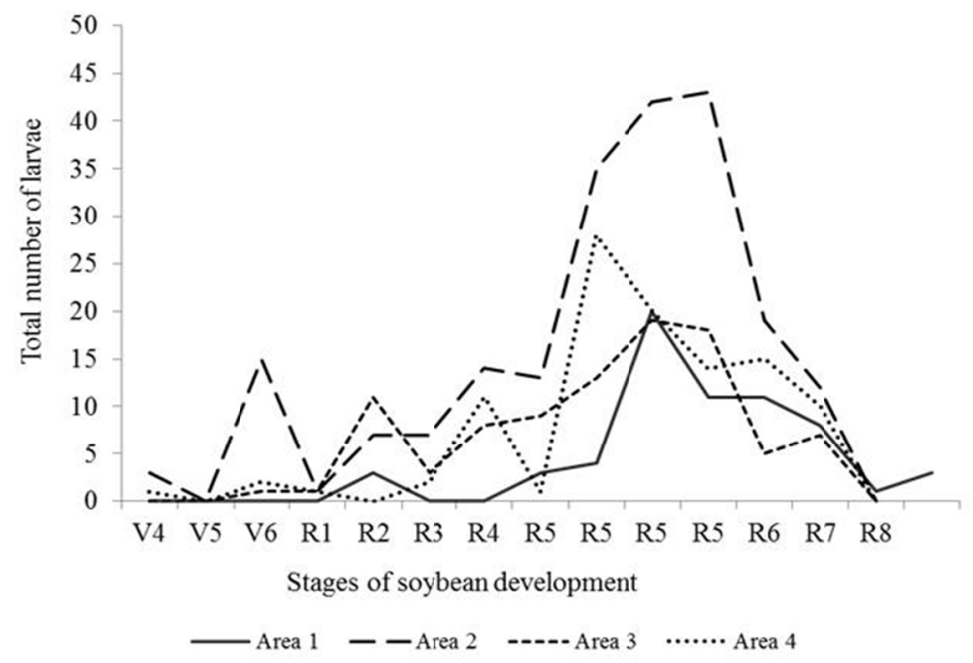

Figure 2. Population dynamics of Omiodes indicata in four soybean areas, Botucatu, São Paulo State, Brazil

$O$. indicata occurred in greater quantities during the reproductive period of the soybean. The fact that this lepidopteran causes defoliation during a period in which photosynthesis is fundamental for the filling of the grains in the R5 stage is alarming because this can have consequences to the final production of the crop. Barros et al. (2002) observed that the greatest reduction in grain yield occurs when the plants undergo defoliation in the R4 and R5 stages, which reinforces the concern placed on the presence and population increase of this pest in soybean cultivation. According to the recommendations by Embrapa (2010), the control of defoliating insects should be carried out when soybean defoliation reaches $15 \%$ at the reproductive stage, since all photoassimilates produced are directed to the formation of flowers, pods and seeds.

It should be emphasized that with their habit of curling in the leaves, the larvae are difficult to collect using the beat cloth method, which means that the present populations are probably underestimated. With this knowledge, it is recommended that plants be inspected to have a more precise estimate of the population.

Although this lepidopteran has already been reported in soybean producing states in Brazil, the information in the literature regarding when this pest becomes present in the crop and when its population peaks during plant development is scarce. Thus, this research presents promising results regarding its presence throughout the crop cycle, its feeding habit on leaves and its population increase during the reproductive phase of soybean. Our results sound the alert to soybean producers regarding the possibility of occurrence of this pest, and its appropriate management for future crops in this and other regions.

\section{Acknowledgements}

The authors thank CAPES for financing and support for this research and Prof. Sinval Silveira Neto for the identification of the species.

\section{References}

Barros, H. B., Santos, M. M., Pelúzio, J. M., Rocha, R. N. C., Silva, R. R., \& Vendrusco, J. B. (2002). Desfolha na produção de soja (Glycine max 'M-SOY 109'), cultivada no cerrado, Gurupi-TO, Brasil. Bioscience Journal, 18, 5-10.

Bortoli, S. A., Parra, J. R. P., \& Lara, F. M. (1982). Aspectos biológicos de Hedylepta indicata (Fabricius, 1775) (Lepidoptera-Pyralidae) em soja (Glycine max (L.) Merrill), sob condições de laboratório. Anais da Sociedade Entomológica do Brasil, 11, 23-32. 
Bortolotto, O. C., Pomari-Fernandes, A., Bueno, R. C. O., Bueno, A. F., kruz, Y. K. S., Queiroz, A. P., ... Ferreira, R. B. (2015). The use of soybean integrated pest management in Brazil: A review. Agronomy Science and Biotechnology, 1, 25-32.

Boyer, W. P., \& Dumas, W. A. (1963). Soybean insect survey as used in Arkansas. Cooperative Economic Insect Report, 13, 91-92.

Czepak, C., Albernaz, K. C., Vivan, L. M., Guimarães, H. O., \& Carvalhais, T. (2013). Primeiro registro de ocorrência de Helicoverpa armigera (Hübner) (Lepidoptera: Noctuidae) no Brasil. Pesquisa Agropecuária Tropical, 43, 110-113.https://doi.org/10.1590/S1983-40632013000100015

EMBRAPA (Empresa Brasileira de Pesquisa Agropecuária). (2010). Tecnologias de produção de soja região central do Brasil 2011 (p. 255). Embrapa Soja: Embrapa Cerrados: Embrapa Agropecuária Oeste.

Limonte, A. C., Hernández, U. A., Ravelo, H. G., Camacho, R. A. O., \& Morales, M. C. (2016). Entomofauna associated to soybean [Glycine $\max ($ L.) Merr.] in direct seeding and conventional tillage. Centro Agrícola, $43,77-84$.

Moscardi, F., Bueno, A. F., Sosa-Gómez, D. R., Roggia, S., Hoffmann-Campo, C. B., Pomari, A. F., Corso, I. C., ... Yano, S. A. C. (2012). Artrópodes que atacam as folhas da soja. In C. B. Hoffmann-Campo, B. S. Corrêa-Ferreira, \& F. Moscardi (Eds.), Soja: Manejo integrado de insetos e outros artrópodes-praga (pp. 213-334). Brasília: Embrapa.

Plantwise. (2017). Plantwise Knowledge Bank. Retrieved from http://www.plantwise.org/KnowledgeBank/ Datasheet.aspx?dsid=26689

Quintela, E. D., \& Barrigossi, J. A. F. (2005). Opções de Controle Químico da Lagarta Enroladeira, Omiodes indicata no Feijoeiro Comum. Embrapa Arroz e Feijão, Comunicado Técnico 99. Santo Antônio de Goiás, GO.

Sosa-Gómez, D. R., Corrêa-Ferreira, B. S., Hoffmann-Campo, C. B., Corso, I. C., Oliveira, L. J., Moscardi, F., ... Hirose, E. (2010). Manual de identificação de insetos e outros invertebrados da cultura da soja. Embrapa Soja, Documentos 269. Londrina, PR.

Wiest, A., \& Barreto, M. R. (2012). Evolução dos Insetos-Praga na Cultura da Soja no Mato Grosso. Entomo Brasilis, 5, 84-87. https://doi.org/10.12741/ebrasilis.v5i2.173

\section{Copyrights}

Copyright for this article is retained by the author(s), with first publication rights granted to the journal.

This is an open-access article distributed under the terms and conditions of the Creative Commons Attribution license (http://creativecommons.org/licenses/by/4.0/). 